\title{
Glycine Potentiates Strychnine-Induced Convulsions: Role of NMDA Receptors
}

\author{
Alice A. Larson and Alvin J. Beitz \\ Department of Veterinary Biology, University of Minnesota, St. Paul, Minnesota 55108
}

\begin{abstract}
Strychnine poisoning leads to seizures that have traditionally been attributed to competitive antagonism of glycine receptors in the spinal cord. Although glycine is thought to act as an inhibitory neurotransmitter, a strychnine-insensitive glycine $\left(G_{\mid} y_{2}\right)$ receptor has been recently described in cultured mouse neurons that is thought to be allosterically linked to the excitatory amino acid NMDA receptor. The present study demonstrates that intrathecally administered glycine, in contrast to other putative inhibitory transmitters, potentiates rather than inhibits strychnine-induced convulsions in mice. The seizure-potentiating effects of glycine are blocked by aminophosphonovaleric acid, an NMDA antagonist. In addition, in animals pretreated with a subconvulsive dose of strychnine to block strychnine-sensitive glycine receptors $(\text { Gly })_{1}$, glycine enhances, rather than inhibits, NMDA-induced convulsions. Together, these results indicate that the seizure-potentiating effects of glycine involve activation of NMDA receptors. This study provides the first evidence that glycine is capable of modulating the activity of NMDA receptors in the spinal cords of adult animals. In light of the elevated concentrations of glycine found in epileptogenic brain foci, these data also suggest that glycine may be a positive modulator in the production of epileptic seizures.
\end{abstract}

Glycine is a simple amino acid and an essential intermediate in many metabolic processes throughout the body. Research over the past 2 decades suggests that it is also an important inhibitory neurotransmitter in the CNS (Daly and Aprison, 1983). Higher concentrations of glycine are found in the spinal cord than in supraspinal regions (Shaw and Heine, 1965; Aprison et al., 1969; Hall et al., 1976; Elekes et al., 1986). Consistent with its transmitter role, glycine has been localized to presynaptic terminals using both autoradiographic (Ljungdahl and Hökfelt, 1973) and immunohistochemical approaches (Storm-Mathisen et al., 1986; Clements et al., 1989). In addition, synaptosomes derived from medulla, spinal cord (Osborne and Bradford, 1973), and cerebrum (Levi et al., 1982) exhibit a potassium-stimulated, calcium-dependent release of glycine. Further evidence to support glycine's role as an inhibitory transmitter was obtained using electrophysiological approaches that demonstrated gly-

\footnotetext{
Received Nov. 17, 1987; revised Feb. 12, 1988; accepted Mar. 1, 1988.

This work was supported by United States Public Health Service Grants DA04090, DA04190, DE06682, and NS19208 and NSF Grant BNS-8607520. We wish to express our thanks to Drs. David R. Brown and Ilo E. Lcppik for thcir hclpful suggestions in the preparation of this manuscript.

Correspondence should be addressed to Alice A. Larson, Department of Veterinary Biology, 295 Animal Science/Veterinary Medicine Building, University of Minnesota, St. Paul, MN 55108.

Copyright (C) 1988 Society for Neuroscience $0270-6474 / 88 / 103822-05 \$ 02.00 / 0$
}

cine's ability to cause postsynaptic hyperpolarization (Curtis and Watkins, 1960; Werman et al., 1968) by increasing chloride ion conductance (Alger, 1985; Barker, 1985).

Based on strychnine's ability to antagonize glycine (Bradley et al., 1953), several physiologic roles of glycine have been inferred from symptoms of strychnine poisoning, which is characterized by spinal myoclonus, painful responses to sensory stimulation, and distortion of visual and auditory perceptions (Zarbin et al., 1981). These effects of strychnine suggest that glycine receptors are important in the function of sensory, motor, and nociceptive pathways.

In association with its putative transmitter role, elevated glycine concentrations are found in human epileptogenic foci removed during surgery for intractable seizures (vanGelder et al., 1972; Perry and Hansen, 1981), whereas a reduction of glycine content is associated with rigidity (Davidoffet al., 1967; Homma et al., 1979). The role of glycine in the etiology of epilepsy is especially perplexing as seizures are thought to be associated with excessive excitatory, rather than inhibitory, neuronal activity. It was thus of considerable interest when evidence was presented that 2 glycine receptors exist, the classic strychninesensitive inhibitory site ( $\left.\mathrm{Gly}_{1}\right)$ and a newer, strychnine-insensitive site $\left(\mathrm{Gly}_{2}\right)$ (deFeudis et al., 1978; Kishimoto et al., 1981). The existence of a $\mathrm{Gly}_{2}$ receptor has recently been supported using autoradiographic techniques to differentially localize ${ }^{3} \mathrm{H}-$ glycine and ${ }^{3} \mathrm{H}$-strychnine binding sites in the CNS (Bristow et al., 1986) and electrophysiological techniques on a cultured murine neuronal preparation (Johnson and Ascher, 1987). More importantly, this latter in vitro study demonstrated that glycine potentiates the depolarizing effect of $N$-methyl-D-aspartate (NMDA), one of 3 known types of excitatory amino acid receptors. In order to determine whether $\mathrm{Gly}_{2}$ receptors participate in an excitatory effect in vivo and whether this excitation is linked to NMDA receptors in adult animals, we investigated the effect of glycine on the convulsant activity produced by strychnine or NMDA using an exquisitely simple behavioral system in which the effect of drugs can be monitored immediately after their direct injection into the CSF of the spinal cord.

\section{Materials and Methods}

Mice weighing between 17 and 25 gm were injected intrathecally (i.t.) following the method of Hylden and Wilcox (1980) as modified by Larson (1988). This method of drug injection has been successfully exploited by many investigators to examine the effect of various compounds on nociceptive processing or on convulsant activity. All i.t. injections were made in unanesthetized mice at approximately the L-5, L-6 intervertebral space using a 30-gauge $1 / 2$ inch disposable needle on a $50 \mu$ luer tip Hamilton syringe. In order to inject different drugs into the same i.t. space, a PE10 cannula connecting the 30-gauge needle to the syringe was filled with premeasured $5 \mu \mathrm{l}$ volumes of the drug so- 


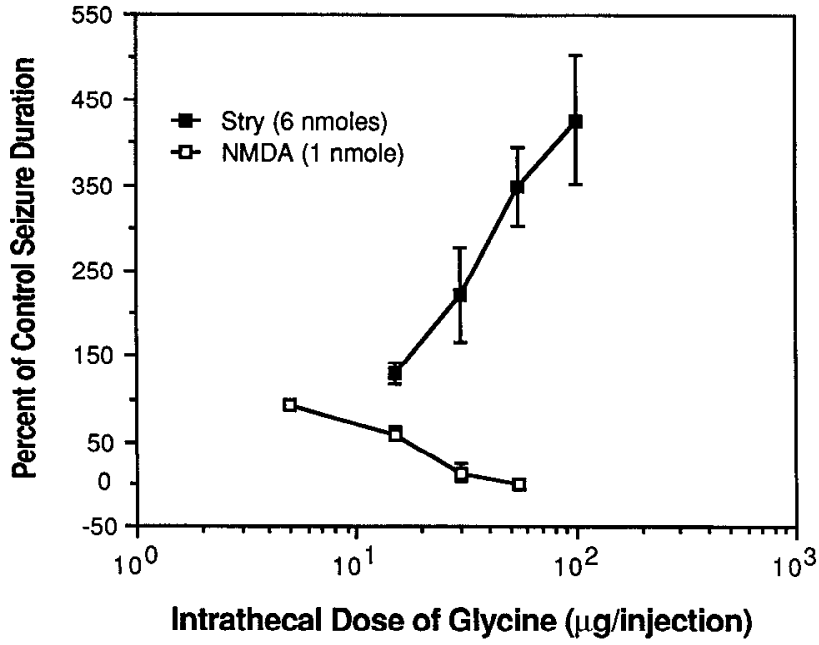

Figure 1. Effect of glycine on strychnine- and NMDA-induced convulsions in mice. Intrathecal injection of $6 \mathrm{nmol}$ strychnine resulted in seizures lasting $180.6 \mathrm{sec}( \pm$ SEM of 25.1$)$, while injection of $1 \mathrm{nmol}$ NMDA produced convulsions lasting $80.7 \mathrm{sec}( \pm$ SEM of 11.6) in duration. The effects of increasing doses of glycine coadministered with these convulsant compounds are expressed as the percentage of these baseline values. Glycine produced opposite effects on the duration of seizures such that a $55 \mu \mathrm{g}$ dose of glycine completely inhibited the convulsant effect of NMDA but potentiated the duration of strychnineinduced convulsants to greater than 3 times the control value. Each point represents the mean $( \pm \mathrm{SEM})$ obtained from at least 6 mice. SEs associated with points on the NMDA curve are quite small and therefore not evident on the graph. The significance $(p<0.001)$ of glycine's effect on the duration of convulsions was determined using a 1-way ANOVA.

lutions separated by an air bubble. All drugs injected i.t. were dissolved in saline for injection in a $5 \mu \mathrm{l}$ volume. Strychnine, glycine, NMDA, taurine, beta-alanine, GABA, and DL-aminophosphonovaleric acid (APV) were purchased from Sigma. The duration of convulsive activity was measured as previously described (Beitz and Larson, 1985).

\section{Results}

Injection of $6 \mathrm{nmol}(2 \mu \mathrm{g})$ of strychnine i.t. in mice produced a convulsive episode beginning within $30 \mathrm{sec}$ after injection, which typically persisted intermittently for $3 \mathrm{~min}$. In contrast, i.t. injection of $1 \mathrm{nmol}(200 \mathrm{ng})$ of NMDA produced an immediate, continuous convulsion lasting slightly longer than $1 \mathrm{~min}$. Doses of convulsants were chosen based on their ability to elicit seizures of sufficient duration to enable measurement of inhibition or potentiation of seizure activity. Coadministration of $6 \mathrm{nmol}$ of strychnine with increasing doses of glycine resulted in a marked and dose-related potentiation, rather than inhibition, of the duration of convulsive activity (Fig. 1). In contrast, coadministration of glycine with $1 \mathrm{nmol}$ NMDA resulted in a dose-related inhibition of seizures. In order to determine the time course of glycine's potentiative effect, $2.4 \mathrm{nmol}$ strychnine was administered at varying times after the i.t. injection of $730 \mathrm{nmol}$ glycine or saline (Fig. 2). Glycine potentiation of strychnine-induced seizure activity was still evident $4 \mathrm{~min}$ after glycine injection.

Intrathecal injection of other putative inhibitory amino acid transmitters at an equimolar dose as glycine $(730 \mathrm{nmol})$ inhibited, rather than potentiated, the duration of strychnine-induced seizures (Fig. $3 A$ ). When administered alone at this dose, betaalanine and taurine caused paralysis, which may simply mask the manifestation of convulsive activity. In contrast to glycine, subparalytic doses of beta-alanine $(337 \mathrm{nmol})$ and taurine $(120$ $\mathrm{nmol}$ ) failed to alter the duration of strychnine-induced convulsions (Fig. $3 B$ ).

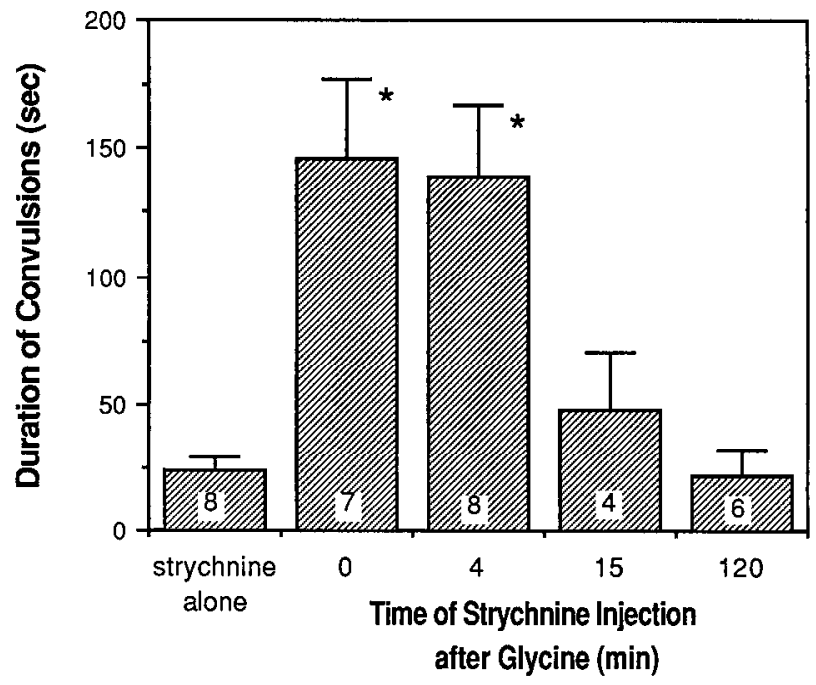

Figure 2. Duration of glycine potentiation of strychnine-induced convulsions. To determine the time course of glycine's effect on strychnineinduced seizures, $55 \mu \mathrm{g}$ glycine was injected either together with or at various times prior to injection of $0.8 \mu \mathrm{g}$ strychnine, i.t. The potentiating effect of glycine lasted at least $4 \mathrm{~min}$, as shown above. Asterisks indicate a significant increase $(p<0.01)$ in the mean convulsive episode due to glycine treatment compared with the strychnine control value, as determined using a 1-way ANOVA, followed by Tukey's multiple-comparison procedure. Each bar represents the mean $( \pm$ SEM) of the duration of convulsions, and the value at the base of each bar represents the number of mice tested.

Glycine inhibition of NMDA seizures, as shown in Figures 1 and 4, appears to result from an interaction of glycine with an inhibitory glycine receptor. If this inhibitory receptor is strychnine-sensitive, antagonism by a subconvulsive dose of strychnine would be expected to unmask an excitatory effect of glycine at the NMDA-linked $\mathrm{Gly}_{2}$ receptor. This was tested by pretreatment of mice with either saline or $0.3 \mathrm{nmol}$ strychnine followed $30 \mathrm{sec}$ later by the injection of either $1.36 \mathrm{nmol}$ NMDA alone or NMDA plus $730 \mathrm{nmol}$ glycine. For these injections, the 30gauge needle was attached to the microsyringe via a PE 10 cannula filled with the appropriate drugs. This allows the sequential injection of 2 different drug solutions into the same intrathecal site rather than requiring 2 separate injections. The convulsive response to i.t. NMDA alone was not altered by strychnine pretreatment (Fig. 4). In addition, administration of glycine $30 \mathrm{sec}$ after this subconvulsive dose of strychnine failed to elicit seizures. Following strychnine administration, however, glycine potentiated, rather than inhibited, NMDA-induced convulsions (Fig. 4).

In order to further examine whether glycine potentiation of strychnine-induced convulsions is associated with NMDA activity, this potentiation was measured in the presence of APV, a selective antagonist at the NMDA excitatory amino acid receptor (Watkins and Olverman, 1987). While glycine was again found to potentiate strychnine-induced seizures, coadministration of $1 \mathrm{nmol}$ APV blocked this facilitation (Fig. 5). The same dose of APV, on the other hand, had no effect on strychnineinduced seizures.

\section{Discussion}

Our results are consistent with the existence of 2 glycine receptor subtypes, a strychnine-sensitive and a strychnine-insensitive subtype. While the hypothesis that there are 2 glycine receptors 

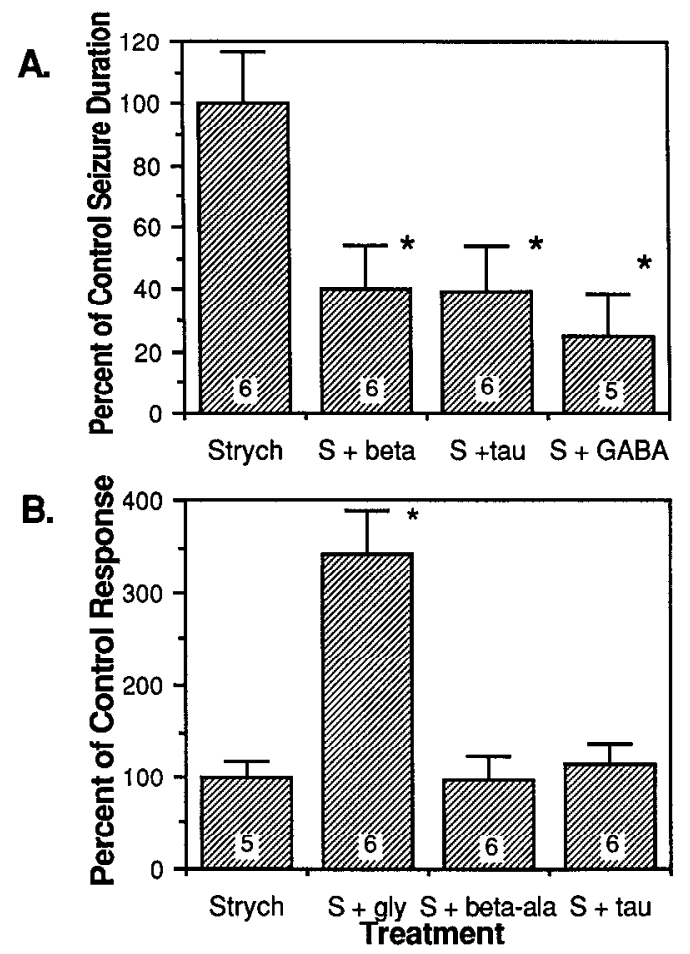

Figure 3. Effect of other small, inhibitory compounds on strychnineinduced seizures. $A$, Coadministration of $730 \mathrm{nmol}$ of either beta-alanine, taurine, or GABA significantly inhibited the seizures produced by $6 \mathrm{nmol}$ strychnine. $B$, While coadministration of a subparalytic dose of glycine $(730 \mathrm{nmol})$ potentiated strychnine-induced convulsions, subparalytic doses of beta-alanine $(337 \mathrm{nmol})$ and taurine $(120 \mathrm{nmol})$ failed to alter the duration of strychnine-induced seizures. Each bar represents the mean percentage of control ( \pm SEM) obtained from 5-6 mice, as indicated by the value at the base of each bar. The significance of increases or decreases in the duration of convulsions was determined by ANOVA followed by Tukey's multiple-comparison procedure ( $p<$ $0.05)$.

is not new, the suggestion that the $\mathrm{Gly}_{2}$ receptor is associated with excitatory, rather than inhibitory, effects has only recently been postulated by Johnson and Ascher (1987) based on their work with cultured embryonic mouse neurons. Our results extend their findings by demonstrating, for the first time, an in vivo excitatory effect of the Gly ${ }_{2}$ receptor in adult animals. Based on data obtained from electrophysiological studies, Johnson and Ascher (1987) proposed an allosteric effect of glycine at the NMDA receptor. Recent binding studies have strengthened this hypothesis by demonstrating that glycine modulates ${ }^{3} \mathrm{H}-\mathrm{MK}$ 801 and ${ }^{3} \mathrm{H}-\mathrm{TCP}$ binding to the NMDA receptor complex in adult rat brain homogenates (Bonhaus et al., 1987; Wong et al., 1987). In the present study, we demonstrate that glycine's potentiation of strychnine-induced convulsions is, in fact, associated with NMDA activity as this potentiation was inhibited by APV, a selective antagonist at the NMDA excitatory amino acid receptor (Watkins and Olverman, 1987). The same dose of APV, on the other hand, had no effect on strychnine-induced seizures. This demonstrates that the $\mathrm{Gly}_{2}$ response is mediated by activation of an NMDA receptor.

These data also suggest that the NMDA modulatory site does not appear to be saturated with interstitial glycine in the spinal cord as exogenous glycine was effective. Thus, the consequence of changes in glycine concentrations or, alternatively, changes in the density of $\mathrm{Gly}_{2}$ receptors may play a role in epileptic

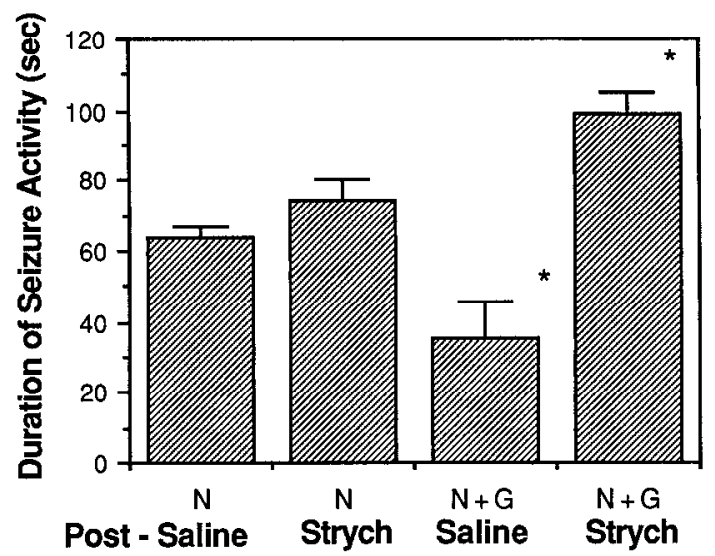

Figure 4. Blockade of strychnine-sensitive glycine receptors $\left(\mathrm{Gly}_{1}\right)$ unmasks an excitatory effect of glycine $\left(\mathrm{Gly}_{2}\right)$ on NMDA-induced convulsions. All mice were prepared for repeated injections by intrathecally implanting a 30 -gauge needle connected by polyethyene tubing to a 50 $\mu l$ Hamilton syringe. Mice were injected with either saline or a subconvulsive dose of strychnine $(0.3 \mathrm{nmol})$ and $30 \mathrm{sec}$ later challenged with NMDA $(1.36 \mathrm{nmol})$ or NMDA plus glycine $(730 \mathrm{nmol})$. Glycine alone failed to elicit convulsions in 5 strychnine-pretreated mice (data not shown). Shown above, strychnine pretreatment had no effect on the duration of NMDA-induced seizures. Although glycine had an inhibitory effect on the duration of NMDA-induced seizures in saline-pretreated animals, it had a potentiating effect in strychnine-pretreated mice. Asterisks indicate significant changes in the mean duration of seizures induced by glycine compared with the effect of NMDA in salinepretreated mice. Each bar represents the mean $( \pm$ SEM) value obtained from 5 animals. Significance was determined using ANOVA followed by Tukey's multiple-comparison procedure $(p<0.01)$.

conditions. The concentration of glycine in the extracellular fluid of rat spinal cord has recently been found to be $13.19 \mu \mathrm{M}$ (Skilling et al., 1988). The actual concentration of glycine in the area of its receptors, however, as well as the concentration achieved after the i.t. injection of this amino acid are both unknown. Thus, the concentration of glycine necessary to activate the Gly ${ }_{2}$ receptor in vivo in both normal and pathological states remains to be determined.

The synergism between the NMDA and $\mathrm{Gly}_{2}$ receptors may be important both physiologically and in certain clinical disorders. The observation that pretreatment with glycine potentiates strychnine-induced seizures for several minutes (Fig. 2) in combination with the finding that this facilitation is mediated by NMDA suggests that glycine may produce a long-term enhancement of excitatory amino acid transmission in the CNS. Indeed, spinal neurons grown in a medium containing $0.4 \mathrm{~mm}$ glycine differed from spinal neurons grown in a glycine-free medium by an increased paroxysmal excitatory neuronal activity (Nelson et al., 1977).

Synergistic interactions between glycine and excitatory amino acids may be predicted in certain brain areas based on the marked similarity in distribution of NMDA binding sitcs and $\mathrm{Gly}_{2}$ binding sites compared with the distribution of tritiated strychnine binding sites (Cotman et al., 1987). There are, in fact, no apparent ${ }^{3} \mathrm{H}$-strychnine binding sites in the cerebral cortex, hippocampus, and striatum, which contain the highest concentrations of $\mathrm{Gly}_{2}$ binding sites (Bristow et al., 1986). This differential distribution of 2 types of glycine binding sites may have important implications in the etiology or pathology of epilepsy where glycine concentrations are elevated (vanGelder et al., 1972; Perry and Hansen, 1981). Glycine is also elevated in the chronic epileptogenic focus in animals with cobalt-induced seizures 


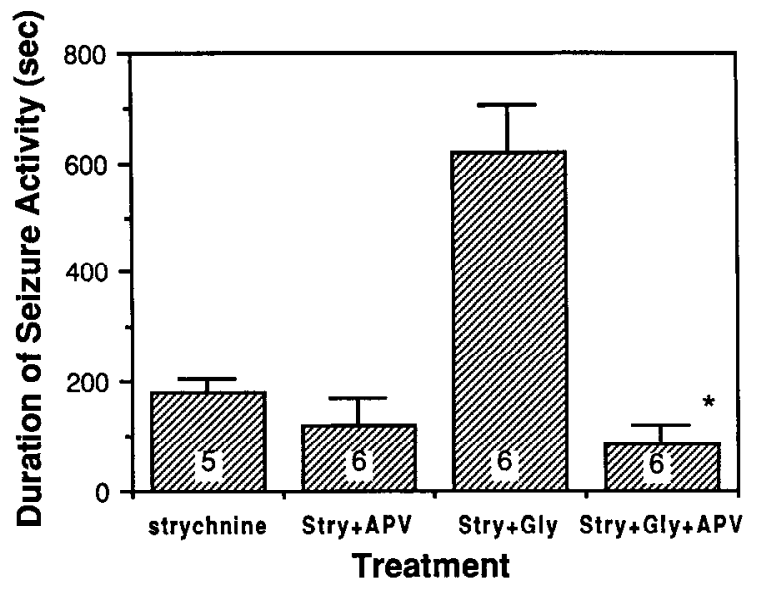

Figure 5. Inhibition of glycine's excitatory effect by APV, an NMDA antagonist. Coadministration of $d l$-amino-phosphonovaleric acid (APV); $(1 \mathrm{nmol})$, an NMDA-type excitatory amino acid receptor antagonist, with strychnine $(6 \mathrm{nmol})$ had no effect on the duration of strychnineinduced convulsions. However, APV completely blocked the glycineinduced potentiation of strychnine-induced seizures, suggesting that glycine's potentiating effect is linked to NMDA receptors. Each bar represents the mean $( \pm \mathrm{SEM})$ duration of seizure activity, and the value at the base of each bar represents the number of mice tested. Significance was determined by ANOVA followed by Tukey's multiple-comparison procedure $(p<0.01)$.

(vanGelder and Courtois, 1972). The presense of $\mathrm{Gly}_{2}$ receptors in brain areas implicated in epilepsy would provide a mechanism whereby glycine may enhance the generation and propagation of seizure activity.

The potentiation of strychnine appears to be specific for glycine as other putative inhibitory transmitter compounds inhibit, rather than prolong, the duration of strychnine-induced seizures. We have previously shown that GABA inhibits picrotoxin- and bicuculline-induced convulsions (Beitz and Larson, 1985), which is consistent with a mechanism involving competitive inhibition of an inhibitory receptor. Our present results showing potentiation by glycine of strychnine-induced convulsions are thus in distinct contrast to the interactions between GABA and convulsant compounds that are thought to interact at the GABA receptor. The ability of taurine and beta-alanine to inhibit ${ }^{3} \mathrm{H}$ strychnine binding, as indicated by their $\mathrm{IC}_{50}$ values, is almost identical to that of glycine (Marvizon et al., 1986). Alternatively, the inhibitory effect of beta-alanine, taurine, and GABA on strychnine-induced seizures may be produced by an interaction of these compounds with their own inhibitory receptors (McBride and Frederickson, 1980; Yarbrough et al., 1981) as they display a relatively low ability or are unable to displace strychnineinsensitive ${ }^{3} \mathrm{H}$-glycine binding (Bristow and Bowery, 1986).

This report describes the novel finding that glycine potentiates the convulsive effect of strychnine when injected i.t., indicating that a $\mathrm{Gly}_{2}$ receptor is present in the CNS and that interaction of glycine with this receptor leads to excitatory rather than inhibitory effects in vivo. These results further demonstrate that the $\mathrm{Gly}_{2}$ receptor in the spinal cord may be functionally linked to an NMDA receptor.

\section{References}

Alger, B. E. (1985) GABA and glycine: Postsynaptic actions. In Neurotransmitter Actions in the Vertebrate Nervous System, M. A. Rogawski and J. L. Barker, eds., pp. 33-69, Plenum, New York.
Aprison, M. H., R. P. Shank, and R. A. Davidoff (1969) A comparison of concentrations of glycine, a transmitter suspect, in different areas of the brain and spinal cord in seven different vertebrates. Comp. Biochem. Physiol. 28: 1345-1355.

Barker, J. L. (1985) GABA and glycine: Ion channel mechanisms. In Neurotransmitter Actions in the Vertebrate Nervous System, M. A. Rogawski and J. L. Barker, eds., pp. 71-100, Plenum, New York.

Beitz, A. J., and A. A. Larson (1985) Inhibition of intrathecally administered picrotoxin- and bicuculline-induced convulsions in mice by pipecolic acid or GABA. Eur. J. Pharmacol. 114: 181-187.

Bonhaus, D. W., B. C. Burge, and J. O. McNamara (1987) Biochemical evidence that glycine allosterically regulates an NMDA receptor-coupled ion channel. Eur. J. Pharmacol. 142: 489-490.

Bradley, K., E. M. Easton, and J. C. Eccles (1953) An investigation of primary or direct inhibition. J. Physiol. (Lond.) 122: 474-488.

Bristow, D. R., N. G. Bowery, and G. N. Woodruff (1986) Light microscopic localisation of $\left[{ }^{3} \mathrm{H}\right]$ glycine and $\left[{ }^{3} \mathrm{H}\right]$ strychnine binding sites in rat brain. Eur. J. Pharmacol. 126: 303-307.

Clements, J. R., K. R. Magnusson, and A. J. Beitz (1989) Ultrastructural description of glutamate-, aspartate-, taurine-, and glycine-like immunoreactive terminals from five rat brain regions. In Electron Microscopy of Synapses, A. J. Beitz, G. A. Mihailoff, B. Maley, and J. Hamos, eds., Liss, New York (in press).

Cotman, C. W., D. T. Monaghan, O. P. Ottersen, and J. Storm-Mathisen (1987) Anatomical organization of excitatory amino acid receptors and their pathways. Trends Neurosci. 10:273-280.

Curtis, D. R., and J. C. Watkins (1960) The excitation and depression of spinal neurons by structurally related amino acids. J. Neurochem. 6: 117-141.

Daly, E. C., and M. H. Aprison (1983) Glycine. In Handbook of Neurochemistry, Vol. 3, Metabolism in the Nervous System, A. Lajtha, ed., pp. 467-499, Plenum, New York.

Davidoff, R. A., L. T. Graham, Jr., R. P. Shank, R. Werman, and M. H. Aprison (1967) Changes in amino acid concentrations associated with loss of spinal interneurons. J. Neurochem. 14: 1025-1031.

deFeudis, F. V., L. M. Orsensanz-Munoz, and J. L. Fando (1978) High affinity glycine binding sites in rat CNS: Regional variation and strychnine sensitivity. Gen. Pharmacol. 9: 171-176.

Elekes, I., A. Patthy, T. Lang, and M. Palkovits (1986) Concentrations of GABA and glycine in discrete brain nuclei. Stress-induced changes in the levels of inhibitory amino acids. Neuropharmacology 25: 703709.

Hall, P. V., J. E. Smith, R. L. Campbell, R. L. Felten, and M. H. Aprison (1976) Neurochemical correlates of spasticity. Life Sci. 18: 14671471 .

Homma, S., T. Suzuki, S. Murayama, and M. Otsuka (1979) Amino acid and substance $P$ contents in spinal cord of cats with experimental hind-limb rigidity produced by occlusion of spinal cord blood supply. J. Neurochem. 32: 691-698.

Hylden, J. L. K., and G. L. Wilcox (1980) Intrathecal morphine in mice: A new technique. Eur. J. Pharmacol. 67: 313-316.

Johnson, J. W., and P. Ascher (1987) Glycine potentiates the NMDA response in cultured mouse brain neurons. Nature 325: 529-531.

Kishimoto, H., J. R. Simon, and M. H. Aprison (1981) Determination of the equilibrium dissociation constants and number of glycine binding sites in several areas of the rat central nervous system using a sodium-independent system. J. Neurochem. 37: 1015-1024.

Larson, A. A. (1988) Desensitization to intrathecal substance $P$ in mice: Possible involvement of opioids. Pain 32: 367-374.

Levi, G., G. Bernardi, E. Cherubini, V. Gallo, M. G. Marciani, and P. Stanzione (1982) Evidence in favor of a neurotransmitter role of glycine in the rat cerebral cortex. Brain Res. 236: 121-131.

Ljungdahl, A., and T. Hökfelt (1973) Autoradiographic uptake patterns of $\left({ }^{3} \mathrm{H}\right)$ GABA and $\left({ }^{3} \mathrm{H}\right)$ glycine in central nervous tissues with special reference to the cat spinal cord. Brain Res. 62: 587-595.

Marvizon, J. C. G., J. Vazquez, M. G. Calvo, F. Mayor, Jr., A. R. Gomez, F. Valdivieso, and J. Benavides (1986) The glycine receptor: Pharmacological studies and mathematical modeling of the allosteric interaction between the glycine and strychnine binding sites. Mol. Pharmacol. 30: 590-597.

McBride, W. J., and R. C. A. Frederickson (1980) Taurine as a possible inhibitory transmitter in the cerebellum. Fed. Proc. 39: 2701-2705.

Nelson, P. G., B. R. Ransom, M. Henkart, and B. N. Bullock (1977) Mouse spinal cord in cell culture. IV. Modulation of inhibitory synaptic function. J. Neurophysiol. 40: 1178-1187. 
Osborne, R. H., and H. F. Bradford (1973) Patterns of amino acid release from nerve-endings isolated from spinal cord and medulla. $\mathrm{J}$. Neurochem. 21: 407-419.

Perry, T. L., and S. Hansen (1981) Amino acid abnormalities in epileptic foci. Neurology (NY) 31: 872-876.

Shaw, R. K., and J. D. Heine (1965) Ninhydrin positive substances present in different areas of normal rat brain. J. Neurochcm. 12:151155.

Skilling, S. R., D. H. Smullin, A. J. Beitz, and A. A. Larson (1988) Extracellular amino acid concentrations in the dorsal spinal cord of freely moving rats following veratridine and nociceptive stimulation. J. Neurochem. 51; 127-132.

Storm-Mathisen, J., O. P. Ottersen, and S. Davanger (1986) The immunocytochemical demonstration of small transmitter molecules: Visualization of glycine in inhibitory neurons. Soc. Neurosci. Abstr. 12: $771(213.8)$

vanGelder, N. M., and A. Courtois (1972) Close correlation between changing content of specific amino acids in epileptogenic cortex of cats and severity of epilepsy. Brain Res. 43: 477-484.
vanGelder, N. M., A. L. Sherwin, and T. Rasmussen (1972) Amino acid content of epileptogenic human brain: Focal versus surrounding regions. Brain Res. 40: 385-395.

Watkins, J. C., and H. J. Olverman (1987) Agonists and antagonists for excitatory amino acid receptors. Trends Neurosci. 10: 265-272.

Werman, R., R. A. Davidoff, and M. H. Aprison (1968) Inhibitory action of glycine on spinal neurons in the cat. J. Neurophysiol. 31: $81-95$.

Wong, E. H. F., A. R. Knight, and R. Ransom (1987) Glycine modulates $\left[{ }^{3} \mathrm{H}\right] \mathrm{MK}-801$ binding to the NMDA receptor in rat brain. Eur. J. Pharmacol. 142: 487-488.

Yarbrough, G. G., D. K. Singh, and D. A. Taylor (1981) Neuropharmacological characterization of a taurine antagonist. J. Pharmacol. Exp. Ther. 219: 604-613.

Zarbin, M. A., J. K. Wamsley, and M. J. Kuhar (1981) Glycine receptor: Light microscopic autoradiographic localization with $\left[{ }^{3} \mathrm{H}\right]$ strychnine. J. Neurosci. 1: 532-547. 